\title{
Mathematics Education and Information Technologies in Emerging Economies
}

\author{
Maria Andrade-Arechiga ${ }^{1}$, Gilberto Lopez ${ }^{2}$, JRG Pulido ${ }^{1}$ \\ ${ }^{1}$ Faculty of Telematics, University of Colima, Colima, México \\ ${ }^{2}$ Department of Computer Science, Center for Scientific Research and \\ Higher Education at Ensenada, Ensenada, México \\ Email:mandrad@ucol.mx,glopez@cicese.mx,jrgp@ucol.mx
}

Received August 28 ${ }^{\text {th }}$, 2013; revised September $28^{\text {th }}$, 2013; accepted October $6^{\text {th }}, 2013$

\begin{abstract}
Copyright (c) 2013 Maria Andrade-Arechiga et al. This is an open access article distributed under the Creative Commons Attribution License, which permits unrestricted use, distribution, and reproduction in any medium, provided the original work is properly cited.
\end{abstract}

\begin{abstract}
International studies indicate that some countries are failing to produce enough quality graduates in Science and Engineering (S \& E). Unfortunately, basic research and strong structured initiatives in S \& E education are scarce in these countries. We take México as a case study and examine university teachers' beliefs and perceptions on some aspects of the learning-teaching process of university mathematics and their opinions in the inclusion of Information Technologies (IT) in the S\&E educational process. Analysis of the results indicates that students are failing in critical aspects of the mathematics learning process. The information collected results pivotal in the development and implementation of successful IT based educational initiatives. It is especially important in countries that possess non-homogeneous socioeconomic, cultural, technical and educational settings.
\end{abstract}

Keywords: Science and Engineering; Education in Emerging Economies; Teachers’ Perception; Teaching and Learning with IT

\section{Introduction}

The combination of education and technology has been considered the main key to human progress (Montaser, Mortada, \& Fawzy, 2012). Particularly, technological innovation is associated with education in Science and Engineering (S \& E). Over the past decades, some countries have evidenced concern for the issue and important studies, as well as strong initiatives (e.g. King, 2008; Bourguignon, 2006; Bouvier, 2011; Brown, 2009; King, 2007; Kuenzi, 2008; NSF, 2006-2010), have resulted. Nowadays, the subject thrives across physical and cultural borders. Moreover, economic development on a global scale requires that investment flows from developed countries to weaker economies to encounter technically literate workforces. The issue, therefore, is no longer local in scale, but global.

Unfortunately, information is scarce for many other countries and what we know derives from general reports on education (e.g. UNESCO, 2011; OECD, 2006). International studies (Schwab, 2008-2010; IESALC, 2006-2009; NSF, 2006-2010) show that some countries, with most in Latin America, have not been successful in substantially increasing the rate at which citizens obtain S \& E university degrees. Puryear \& Ortega Goodspeed (2011) argue that greater emphasis should be placed on improving quality and strengthening Science and Technology at Latin America universities. Likewise, reports on major and emerging economies, published annually by the World Economic Forum (Schwab, 2008-2010) indicate that Latin America countries rank low on "Availability of scientists and engineers”. Of the 133 countries considered in the 2008-2009 report, Costa Rica ranked 46th, and subsequently 29th (of 134 countries) in 2009-2010 and 28th (of 136 countries) in 20102011, ranking only behind Chile (35th, 23rd and 24th), but well above other Latin America countries, such as Argentina (81st, 84th and 76th), Brazil (57th, 60th and 68th), Colombia (88th, 89th and 86th), and Mexico (105th, 94th and 89th). Even more alarming are the placements obtained in the reports in "Higher Education and Training: Quality of Math and Science Education", in which only Costa Rica ranked in the top half. Costa Rica obtained a ranking of 64th, 55th and 50th in the 20082009, 2009-2010 and 2010-2011 reports, respectively. The other Latin America countries ranked well behind: Colombia ranked 79th, 86th and 93rd, Argentina ranked 98th, 98th and 106th, Chile ranked 107th, 116th and 123rd, Brazil obtained a ranking of 124th, 123rd and 126th, and Mexico ranked 127th, 127 th and 128th.

The above situation can be associated with the whole pretertiary educational system (K1-K12) in the region, and is consistent with the negative results obtained by Latin America countries in the PISA evaluations (OECD, 2003, 2006) and other international reports (UNESCO, 2009, 2011; Puryear \& Ortega Goodspeed, 2011). However, direct firsthand information is needed in order to understand, in general, how prepared students are for the specific demands in the disciplines that characterize S \& E university programs.

In many cases, no more time can be wasted. It makes no sense to wait for educational reforms to start giving results in the pre-university levels because at least one more generation would be lost. The situation calls for immediate actions; initially, by trying to understand some fundamental principles in the teaching and learning process of these disciplines. 
Overcoming the problems associated with the teaching and learning process of college mathematics has constituted a goal of many institutional and academic efforts worldwide (e.g. Brown, 2009; Demlová, 2008; Mustoe, 2002; Bass, 2005). Here, we focus on first-year college mathematics courses (e.g., college algebra, linear algebra, calculus) in S \& E. This serves our purpose methodologically, because it is a constant in the $\mathrm{S} \& \mathrm{E}$ disciplines. Moreover, mathematical knowledge and developing mathematics competencies are of a fundamental nature in S \& E. Nevertheless, there are several important issues related to the teaching and learning process that requires more study, especially from the teachers' perspective.

The inclusion of new learning schemes that include innovative teaching materials should be of the greatest importance. Those that feature information technologies (IT) as a tool to improve student learning, especially in mathematics, are of particular interest. Again, we encounter an important cultural and regional bifurcation. Over the last two decades, some countries have made important advances in introducing technology-based instruction in the math classroom at different levels of formal education. Important initiatives (NSF, 2006-2010; Brown, 2009; Kuenzi, 2008), large scale projects, and relevant research (Mustoe, 2002; Neto et al., 2003; Nguyen et al., 2006) have followed.

In Latin America, few general guidelines (UNESCO, 2011) and isolated efforts have been developed (Lopez-Morteo \& Lopez, 2007; Madrigal \& Gozalo, 2007). Controversial and expensive programs like the Mexican Enciclomedia project (SEP, 2004), which required millions of US dollars in investment, produced no significant educational results due to poor teacher training, inadequate school infrastructure, educational model and, more importantly, teacher attitudes toward technology. The government terminated the program in 2009. Evidently, we must address the issues of accessibility, availability, and teacher attitudes toward technology, as described by Oncu et al. (2008), if we hope to incorporate technological supports in the educational process.

Here, we present a series of indicators of the academic problems that become impairing elements in S \& E education in Mexico from the teachers' perspective, including teachers' disposition and attitude toward incorporating IT into the classroom. The use of teacher perception has proven to be an important technique for investigating and evaluating different aspects of the learning and teaching process (Carnell, 2007; Popovic, 2010; Chang et al., 2011). For the purpose of this study, we created and implemented the VEAD survey (Spanish acronym for Valuation of Teaching Activities) to collect information directly from Mexican university S \& E math lecturers on different aspects of their teaching activities.

We argue that this type of information is much more important for initiatives that seek to use IT in education in developing countries that are marked by heterogeneity, than in the richer economies where the educational setting is much more homogeneous. In order to avoid failure in the introduction of the technology into the classroom, some countries still need to determine basic matters. Under the WWECFT (What is Wrong with Education cannot be Fixed with Technology) principle, specific problems in the learning-teaching process must be identified. The type of learning outcomes that are expected from the IT implementation must also be determined. Also, information of a series of practical issues must be acquired, including teachers' attitudes and beliefs about technology's role in their practice, and those related with infrastructure and schools' decision making policies.

\section{S \& E Education in Mexico}

The S \& E Indicators, published by the National Science Foundation (NSF) in the United States, show that less than 2\% of the university-age population in Mexico earned degrees in Natural Science and Engineering (NS \& E) in 2000. This figure is substantially lower than in other countries. In some European Union and Asian countries, it is over $10 \%$, whereas in Canada and the United States the number of NS \& E degrees per 24-year-olds is more than three times the degrees earned in Mexico (NSF, 2006-2010).

Data published by the Organization for Economic Cooperation and Development (OECD) shows that out of its 30 members, Mexico had the fewest Engineering and Exact Sciences degree holders per capita (OECD 2003, 2006, 2007). Countries like Finland and South Korea produced almost five times as many Tertiary-Type A and advanced research program degree holders in Engineering per capita than Mexico between 2000 and 2004 (Figure 1). In Spain and Australia, the number is twice that of Mexico.

In general, most OECD countries have increased their number of degree holders. Some countries like Denmark have been able to close the gap with other OECD members. Although Mexico shows a slight increase for 2003, the number of degree holders in Engineering decreases substantially in 2004. The situation in regards to the number of Exact Sciences degree holders is even worse (OECD 2006, 2007).

Diverse cultural and academic factors could be associated with the failure to produce more S \& E university graduates. National policies must be established in order to produce programs designed to attract young people to these fields. In the case of Mexico, the number of students, seeking an engineering or technology degree, does not even represent 3\% of the country's total undergraduate population (CONACyT, 2006; INEGI, 2005). Moreover, less than .2\% of all undergraduate students are enrolled in math and physics programs.

In addition, problems associated with low graduation, generational retardation, and high dropout rates require special attention. The Mexican National Association of Universities and Institutions of Higher Education (ANUIES) publishes the number of students enrolled in universities by year, institution, academic program, age, and gender. Although it is the best source of information on higher education in Mexico, its last published report was for 2004 (ANUIES, 1996-2004). Table 1 shows first enrollment, total enrollment, graduates and the degrees earned in E \& T (Engineering \& Technology-including Computer Science) and in E \& NS (Exact \& Natural Sciences) in Mexican institutions from 1996 to 2004. In many cases, however, students graduate (i.e., they finish all their academic units), but they never earn a degree. From the information shown in Table 1, one can estimate that in Mexico of all the students that enroll in E \& T/ES \& $\mathrm{T}$ university programs, roughly $35 \%$, will actually earn a degree.

Based on the data presented above, we can conclude that the yearly dropout rate is $11 \%$ and $15 \%$ of students enrolled in E \& $\mathrm{T}$ and $\mathrm{E} \& \mathrm{NS}$ programs, respectively. On the other hand, the research indicates that dropout rates are much more significant during the first semesters, because students experience significant difficulties with the basic mathematics courses taught in 


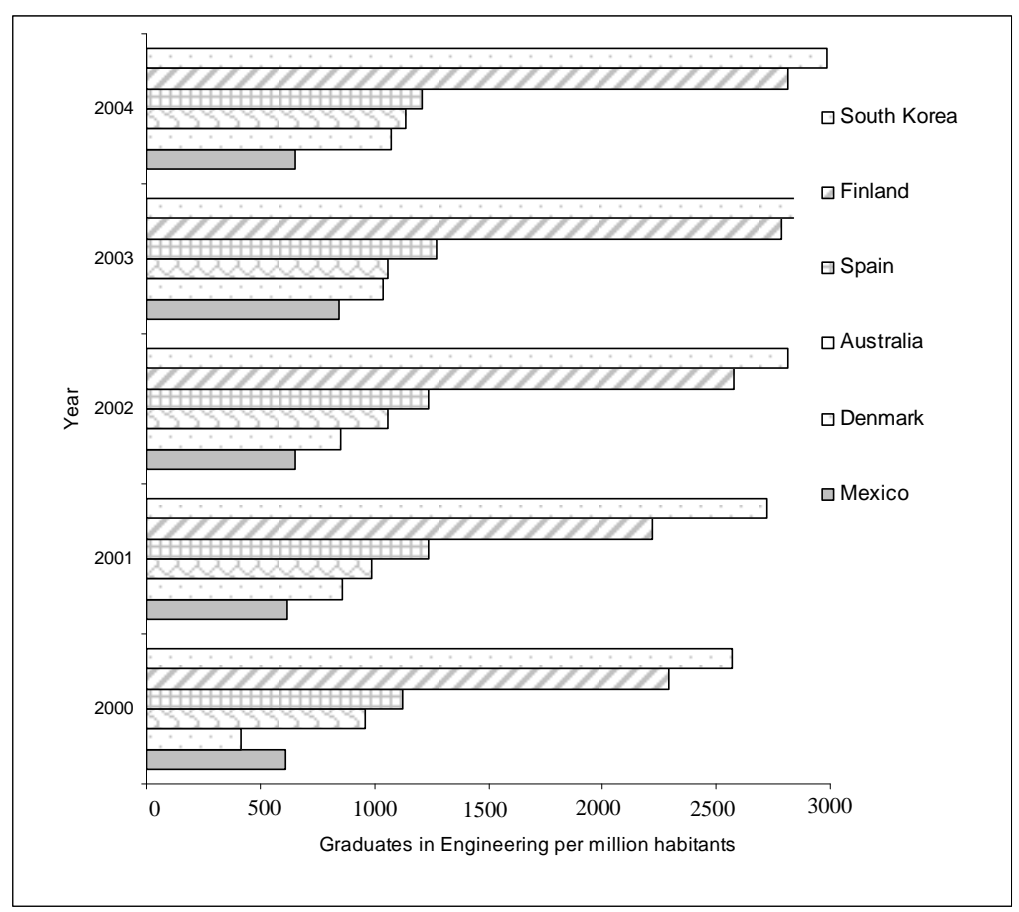

Figure 1.

Tertiary-type A and advanced research program degree holders in engineering for some OECD members, 2000 to 2004 (Source: OECD, 2006).

Natural Science and Engineering university programs (Lazakidou \& Retalis, 2010).

\section{Survey to Valuation of Teaching Activities}

In this study, we sought to obtain lecturers' perceptions on some aspects of their teaching activities, including the use of IT to aide in the teaching process of university level mathematical concepts. Global variables of interest were identified on the teachers' perception of: 1) teaching and learning elements promoted in mathematics courses; 2) the students' learning process; 3) the students' basic mathematics skills; and 4) accessibility, availability, and teachers' attitudes toward using technology in their practices. We conducted four preliminary pilot tests with small groups of university teachers $(\sim 7)$, in order to measure coherence, redundancy, and inconsistency. As a result, some items were modified and others eliminated. Finally, we classified the selected items into sections for the final survey, and utilized a perception-type Likert scale with five ordinal categories for most of the items. A final pilot test was performed in order to obtain Cronbach's alpha coefficient of reliability. The alpha coefficient of $\alpha=.8726$ was obtained, which ensures a high correlations between the items of the test (Garrison et al. 2004). Once the survey was completed, it was made available through a web page and an electronic invitation was extended to more than 800 math lecturers at different institutions across the country.

\section{Results and Discussion}

A total of 145 mathematics lecturers of S \& E university programs answered the survey. Of these, 59.8\% worked at public institutions and $56 \%$ regularly taught courses in the first se- mesters. They reported an approximate student grade point average of 6.7 (on a scale of 10, where 6 is needed to obtain credit) for the courses they taught.

In the first section of the survey, see Table 2, lecturers were asked to express their opinion about the elements they felt were promoted in math university courses (items 1 to 6). Based on the results obtained, it is clear that teachers have a strong opinion on the importance of learning (item 2) and the development of mathematical skills in their classes (item 4). However, the agreement with other essential aspects of the educational process is not as strong. In particular, the importance of teaching (item 1 ) and the fact that only $46 \%$ of the teachers evidenced a degree of agreement with the statement that students develop a genuine interest in mathematics (item 6). Teachers tend to support technical knowledge and development of mathematical skills (items $3 \& 4$ ) rather than emotional-like and motivational aspects of students' learning (items $5 \& 6$ ), the importance of which have been strongly related to the learning of mathematics (Andrade-Arechiga et al., 2013; Cardella, 2008).

The results of teacher perception on different aspects of how students learn mathematics, as well as their capacity to engage in meaningful learning correspond to items 7 to 11 in Table 2. The response to item 9 shows that lecturers agree that students find it difficult to apply mathematical concepts learned in their courses. This is supported by the responses to items 10 and 11 in which the instructors expressed the opinion that students fail to relate successfully previously learned concepts and new ones and to build mathematical knowledge upon them. This behavior has been partially associated with the lack of alternative representations of mathematical knowledge in the learning materials used in traditional courses, where activities are structured to turn composite knowledge into fragmented units that are to be learned separately, without promoting associations with other 
Table 1.

Figures for undergraduate exact sciences and engineering and technology enrollment, Mexico, 1996 to 2004 (ANUIES, 1996-2004).

\begin{tabular}{|c|c|c|c|c|}
\hline \multicolumn{5}{|c|}{ Engineering \& technology } \\
\hline Year & First enrollment & Total enrollment & Graduates* $^{*}$ & Earned degree* \\
\hline 1996 & 95319 & 413208 & 49515 & 27665 \\
\hline 1997 & 103452 & 424352 & 52179 & 30712 \\
\hline 1998 & 112563 & 447405 & 50871 & 29576 \\
\hline 1999 & 126357 & 481543 & 50795 & 31239 \\
\hline 2000 & 136874 & 514463 & 54065 & 34156 \\
\hline 2001 & 145910 & 550636 & 58138 & 37621 \\
\hline 2002 & 156804 & 598929 & 65197 & 39592 \\
\hline 2003 & 157689 & 628188 & 70191 & 43077 \\
\hline 2004 & 159810 & 654580 & 79064 & 49660 \\
\hline \multicolumn{5}{|c|}{ Exact \& natural sciences } \\
\hline Year & First enrollment & Total enrollment & Graduates $^{*}$ & Earned degree ${ }^{*}$ \\
\hline 1996 & 6861 & 22994 & 3321 & 1879 \\
\hline 1997 & 7667 & 25101 & 3210 & 1925 \\
\hline 1998 & 8133 & 27321 & 3021 & 1931 \\
\hline 1999 & 9443 & 30002 & 2738 & 1768 \\
\hline 2000 & 9635 & 32698 & 3023 & 2130 \\
\hline 2001 & 9811 & 33720 & 3163 & 2167 \\
\hline 2002 & 10054 & 34514 & 3755 & 2365 \\
\hline 2003 & 10190 & 35751 & 4674 & 2652 \\
\hline 2004 & 9857 & 36774 & 5021 & 2669 \\
\hline
\end{tabular}

Sources: ANUIES, Anuarios Estadísticos from 1996 to 2004. Undergraduate students at technological universities and institutes. ${ }^{*}$ ANUIES reports the Graduates and Earned degrees from the previous year.

topics already studied within the same curricula. This yields a low or null generation of the mental maps necessary for effective associations (Mustoe 2002; Mason 2001; Boaler 2009). Moreover, if we also consider the results of items 7 and 8, we can infer that teachers believe that some essential elements of the process of learning mathematics are not reaching the students.

Teachers were also asked to express their opinion on students' proficiency on a series of specific mathematical topics, ranging from basic skills to calculus concepts as shown in Table 3 . In general, the results show that teachers think that their students come from low backgrounds and lack pre-university mathematical skills.

These results are seemingly harsh considering that they come from mathematics university teachers. Although negative responses were anticipated, greater positive responses were expected, especially in regards to basic math topics that all students, entering E \& S university program, should master. Items 1-5 are topics taught in the late years of elementary school and secondary school, K5-K15. For these items, $60 \%$ to $70 \%$ of the teachers categorized their students' ability as regular and bad. The responses to math concepts taught at the high-school level and often reinforced in first-year math courses (items 6 to 9), as well as those corresponding to basic Calculus courses (items 10, 11), are also unacceptable for S \& E students. The teachers' responses to items 12 to 14 indicates, that the students are also failing in the problem solving process, a very important element of university mathematics education.

In summary, teachers strongly agree that their students are unable to apply mathematical concepts. In addition, they are not able to relate previously learned concepts to new ones and do not feel they benefit from learning them. They also express the belief that students are unable to apply knowledge to solve problems and fail to find new ways of solving them. From the teachers' responses, we can assume that S \& E students are failing in critical aspects of the mathematics learning process.

Although we would expect $100 \%$ availability of technology in higher education, we recognize that this is still not the case in some countries like Mexico, as shown in Figure 2. Yet, the situation is much better than in other levels of education where a lack of technological resources has been detected (LopezMorteo et al., 2007). Also, teachers' interest in using innovative educational resources and technological supplies (Figure 3) are much higher than those expressed by secondary teachers in the 2007 survey. According to the results, lecturers prefer educational materials adapted to the classroom rather than tools used on distance or mixed environments.

To help reduce this fragmented approach to teaching, we recommend that further research be performed on the creation and adoption of new educational models, along with a broader evaluation on the impact of those materials on students' learning. This initiative can benefit from lecturers' experience and positive attitude in the use of educational software through CD-ROM and online specialized websites (see Figure 3) to develop an integral training program for lecturers on the educational models and strategies associated with the use of this media. Furthermore, these training programs can be complemented with workshops on novel teaching strategies which employ recreational mathematics to promote focus on a problem-solving based approach. The integration of the previous trends can be done through the development of new educational strategies that use an electronic learning environment (online or not), learning models with a problem-oriented approach, interactive software, such as animations, simulations and interactive tools.

On the other hand, we consider that lecturers' professional profiles are a critical factor for implementing new IT-based models, particularly considering their skills and knowledge. In a parallel research done on secondary schools in Mexico, Galaviz-Ferman et al. (2006) found that teachers' positive attitudes on applying new teaching schemes and strategies using IT in mathematics is not enough. In this study, we could say all lecturers stated the intention of using IT; however, due to lack of proper training, its real use has been practically insignificant. This leads us to reinforce the idea that probably the training of university lecturers could influence their use of IT for teaching.

However, at this point we cannot propose a concrete idea regarding curriculum modification due to the high number of factors involved. But starting from our results analysis and the experience other countries have had in this field, we suggest the contents of math courses be modified so they include strategies such as:

- Novel learning models that promote construction of learning and designed not only the transfer of information from teacher to student. 
Table 2.

Teacher perception on important aspects of student learning in university math courses.

\begin{tabular}{|c|c|c|c|c|c|}
\hline & 1: Completely disagree & 2: Disagree & 3: Neutral & 4: Agree & 5: Completely agree \\
\hline Aspect & 1 & 2 & 3 & 4 & 5 \\
\hline 1. Importance of teaching & 2.0 & 6.3 & 24.1 & 45.5 & 22.1 \\
\hline 2. Importance of learning & 2.1 & 3.5 & 8.9 & 32.4 & 53.1 \\
\hline 3. Prominence in technical knowledge & 8.3 & 8.9 & 17.2 & 36.6 & 28.9 \\
\hline 4. Development of mathematical skills & 4.1 & 3.5 & 5.5 & 37.9 & 48.9 \\
\hline 5. The emphasis in students enjoying learning math & 8.3 & 17.2 & 29.7 & 21.4 & 23.4 \\
\hline $\begin{array}{l}\text { 6. That the students develop a } \\
\text { genuine interest in mathematics }\end{array}$ & 6.2 & 18.0 & 29.6 & 27.6 & 18.6 \\
\hline $\begin{array}{l}\text { 7. Students consider mathematics } \\
\text { help them to explore new ideas }\end{array}$ & 6.9 & 32.4 & 20.7 & 26.2 & 13.8 \\
\hline $\begin{array}{l}\text { 8. When students learn mathematics they } \\
\text { perceive it as abstract knowledge }\end{array}$ & 5.5 & 9.7 & 9.7 & 40.0 & 35.2 \\
\hline $\begin{array}{l}\text { 9. Students find it difficult to apply the } \\
\text { mathematical concepts learned in the courses }\end{array}$ & .7 & 2.8 & 4.1 & 32.4 & 60.0 \\
\hline $\begin{array}{l}\text { 10. In math courses, students easily relate } \\
\text { new concepts with previously learned }\end{array}$ & 11.7 & 34.5 & 17.2 & 27.6 & 8.9 \\
\hline $\begin{array}{l}\text { 11. Students build mathematical knowledge } \\
\text { based on previously learned concepts }\end{array}$ & 14.5 & 26.9 & 22.7 & 26.2 & 9.7 \\
\hline
\end{tabular}

Table 3.

Teachers' opinion on university students' proficiency in specific basic math topics.

\begin{tabular}{|c|c|c|c|c|c|}
\hline & 1: Very bad & 2: Bad & 3: Regular & 4: Good & 5: Excellent \\
\hline Topic & 1 & 2 & 3 & 4 & 5 \\
\hline 1. Ability to compute numerical calculations without a calculator & 11.0 & 33.1 & 39.9 & 9.7 & 6.2 \\
\hline 2. Fractions and its operations & 15.9 & 34.5 & 26.9 & 14.5 & 8.3 \\
\hline 3. Algebraic operations & 13.1 & 29.7 & 40.0 & 12.4 & 4.8 \\
\hline 4. Algebraic Factorization & 7.6 & 31.7 & 36.6 & 18.6 & 5.5 \\
\hline 5. Basic geometry and trigonometry & 11.5 & 26.9 & 38.5 & 14.6 & 8.5 \\
\hline 6. High school analytic geometry & 9.0 & 31.7 & 31.0 & 18.6 & 9.7 \\
\hline 7. Real number System & 9.1 & 19.7 & 44.7 & 18.9 & 7.6 \\
\hline 8. Functions and their graphics (including asymptotes, continuous, inverse and composite) & 13.2 & 27.6 & 35.2 & 20.6 & 3.4 \\
\hline 9. Knowledge of specific properties of trigonometric, exponential and logarithmic functions & 21.8 & 30.4 & 36.8 & 8.2 & 2.8 \\
\hline 10. Knowledge and application of derivation and integration formulas & 17.2 & 33.2 & 24.6 & 22.9 & 2.1 \\
\hline 11. Geometrical interpretation of integral and derivative functions & 10.6 & 36.3 & 33.1 & 18.6 & 1.4 \\
\hline 12. Ability to interpret mathematical problems & 25.2 & 33.1 & 29.7 & 9.2 & 2.8 \\
\hline 13. Practical application of mathematical knowledge & 27.6 & 31.5 & 26.9 & 11.9 & 2.1 \\
\hline 14. Ability to establish problem-solving strategies & 22.1 & 33.8 & 30.1 & 11.9 & 2.1 \\
\hline
\end{tabular}

- Training oriented towards the direct application of mathematical knowledge to problem solving.

- Implementing recreational activities as part of the curriculum with the aim of improving the emotional aspect of learning.
- Incorporating technological elements such as learning environments, CD-ROMs, simulations and multimedia contents in activities associated to math teaching.

Another interesting result is that, according to lecturers' perceptions, we learnt that failing math courses contributes, in 


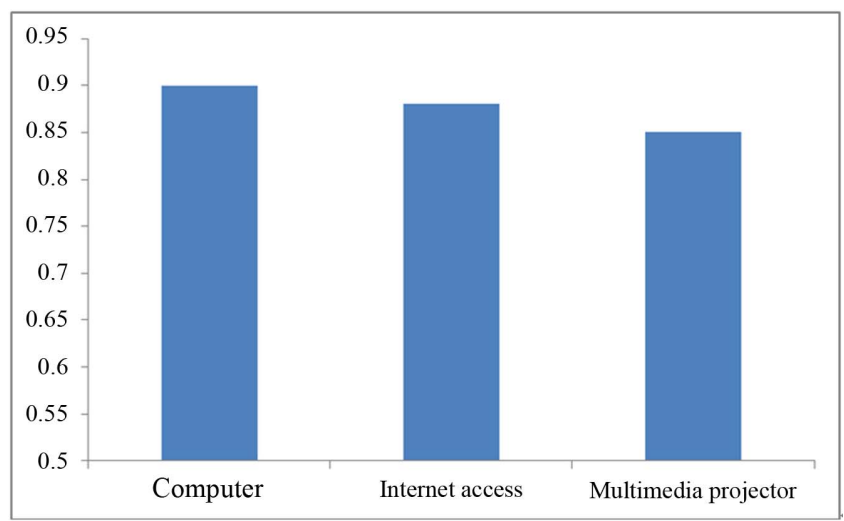

Figure 2.

Availability of computer equipment and peripherals in the classroom.

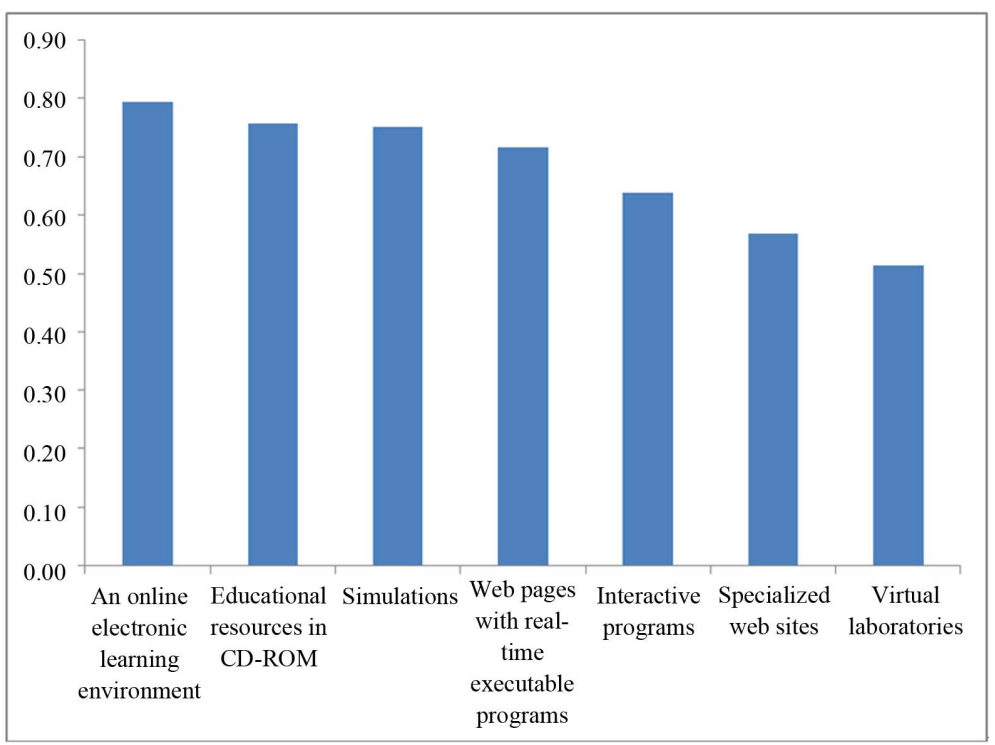

Figure 3.

Technological educational resources and supplies teachers are interested in using.

some way, to undergraduates' decision to drop out. To finish, teachers were asked to comment on the high dropout rates and academic retardation in S \& E programs. Almost $82 \%$ of the lecturers recognized that these problems are directly associated with difficulties students encounter in math courses. In an open-ended question, they also mentioned students' socioeconomic backgrounds and the belief that students wrongfully pursued S \& E degrees as a result of inadequate pre-university counseling and .

Therefore we believe in the need to motivate lecturers on the use of new teaching methods that engage students in math learning. Thus, they can use one or several learning strategies to develop learning activities that allow students to learn by doing, so that they apply their knowledge to solving real-life problems. The latter, teachers' positive attitudes on using technology in education reported by some authors (Bouvier, 2011; Chang et al., 2011; Lazakidou, 2010; Montaser et al., 2012) coincide with the results from this work, indicates there is a great opportunity to enhance the math curricula through the inclusion of alternative activities supported by educational software, selected with the educational objectives of the instructional de- sign in mind. One successful example is the use of online evaluations and laboratories, which improve students' attitudes to and learning of math (Nguyen et al., 2006). The use of electronic learning environments in the classroom is an alternative that has been constantly evolving and improving, which provides an opportunity for universities to promote their benefits and promote their use within the academic community.

The survey developed in this study can be used to diagnose a community of teachers' perceptions on a variety of topics. In this case, we evaluated the perception of a sample of math lecturers from all over the country. However, we believe it can be applied to the teachers of any academic institution to get a feel for the community's perceptions. Thus, policy makers will have a valuable tool with which to diagnose their teaching staff, identify issues that are important to them, as well as specific areas to attend.

An example of a project that could have benefited of having this type of information is the "First World Class Project" (as it was called by several politicians in Mexico) Enciclomedia. The project had an initial budget of 2 thousand million dollars, but only a quarter of that was actually used before it was suspended 
in 2006 (SEP, 2006) because of poor or nonexistent academic results (Elizondo Huerta et al., 2006). A basic study (e.g. Galaviz-Ferman, et al., 2006; Lopez-Morteo et al., 2007) could have given basic information that could have prevented the catastrophic collapse of the project.

In contrast the project PIAC (Interactive Platform for Learning Calculus), designed to help overcome the difficulties associated to learning Calculus (Andrade-Arechiga et al., 2012) was developed and implemented in accordance with the results presented here. The results have shown positive effects of PIAC on different aspects of the learning process. Including an overall acceptance of the platform as well as significant positive attitudes and motivation towards the learning of Calculus (AndradeArechiga, et al., 2012).

\section{Conclusion}

Mexico can be considered as a case study for a large number of countries that fail to produce sufficient quality human resources in S \& E. The data collected from 145 Mexican university mathematics lecturers reveal meaningful insights on a series of indicators of academic problems that hinder advancement in university-level education in Science and Engineering. They express the opinion that their students have not developed conceptual thinking and modeling skills or basic mathematical competencies. The fact that a vast majority of university math teachers think that their students possess limited knowledge of basic (late elementary to high school level) mathematic concepts and lack minimal mathematical skills is alarming, but not completely surprising. It is common practice to trace students' math knowledge deficiencies and weaknesses to previous educational levels. Due to cultural and social similarities, small variants of the scenario shown here can be found in other places, especially many in Latin America.

In order to mitigate the problem it is natural to think that efforts should be directed toward the use of innovative teaching materials including IT as learning alternatives to help in the learning and teaching process. VEAD type information can serve as the building blocks of the IT based educational setting such as in the PIAC project (Andrade-Arechiga et al., 2012). Unfortunately, in many IT in education initiatives, no regard is given to this type of information. This is especially critical when technology is imported from a place where basic educational needs have long been fulfilled. In some cases the introduction of alien technology in the educational system will only serve to expose the educational problems.

The type of information that was collected, any other produced with the goal of identifying critical problems in the learning-teaching process and the type of learning outcomes that are expected from the IT implementation will prove useful in the software design and developmental processes and crucial to the educational results. Nevertheless, in many developing countries, more research, development, and implementations are required to establish general guidelines for the design and development of software and content, as well as the methodological aspects of its implementation in the classroom.

\section{REFERENCES}

Andrade-Arechiga, M., Lopez, G., \& Lopez-Morteo, G. (2012). Assessing effectiveness of learning units under the teaching unit model in an undergraduate mathematics course. Computers \& Education,
59, 594-606.

http://dx.doi.org/10.1016/j.compedu.2012.03.010

Andrade-Arechiga, M., Lopez, G., Pulido, J. R. G., \& Damian-Reyes, P. (2013). Technology for first college mathematics: A teachers’ perspective. Proceedings of Society for Information Technology \& Teacher Education International Conference, New Orleans, 20062011.

ANUIES (1996-2004). Anuarios estadísticos de 1996 a 2004. Población Escolar de Licenciatura en Universidades e Institutos Tecnológicos: ANUIES, 454.

Bass, H. (2005). Mathematics, mathematicians, and mathematics education. American Mathematical Society, 42, 417-430. http://dx.doi.org/10.1090/S0273-0979-05-01072-4

Boaler, J. (2009). Experiencing school mathematics: Traditional and reform approaches to teaching and their impact on student learning, revised and expanded edition (Vol. Mathematical Thinking and Learning Series). Lawrence Erlbaum.

Bourguignon, J. (2006). Mathematics and statistics: Critical skills for Australia's future. The national strategic review of mathematical sciences research in Australia (pp. 1-92).

Bouvier, S. (2011). Increasing student interest in science, technology, engineering, and math (STEM): Massachusetts STEM pipeline fund programs using promising practices. Report Prepared for the Massachusetts Department of Higher Education (p. 74).

Brown, G. (2009). Review of education in mathematics, data science and quantitative disciplines. Report to the Group of Eight Universities. In G. O. Eight (Ed.), 1-14.

Cardella, M. (2008). Which mathematics should we teach engineering students? An empirically grounded case for a broad notion of mathematical thinking. Teaching Mathematics and Its Applications, 27, 150-159. http://dx.doi.org/10.1093/teamat/hrn008

Carnell, E. (2007). Conceptions of effective teaching in higher education: Extending the boundaries. Teaching in Higher Education, 12, 25-40. http://dx.doi.org/10.1080/13562510601102081

Chang, T., Lin, H., \& Song, M. (2011). University faculty members' perceptions of their teaching efficacy. Innovations in Education and Teaching International, 48, 49-60. http://dx.doi.org/10.1080/14703297.2010.543770

CONACyT (2006). Informe general del estado de la ciencia y la tecnología (p. 426). México D.F.: Consejo Nacional de Ciencia y Tecnología.

Demlová, M. (2008). Mathematics education for engineers in the changing world. Report by TREE-Teaching and Research in Engineering in Europe (p. 29).

Elizondo Huerta, A., Paredes Ochoa, F., \& Prieto Hernández, A. (2006). Enciclomedia. Un programa a debate. Revista Mexicana de Investigación Educativa, 11, 209-224.

http://www.redalyc.org/articulo.oa?id=14002811

Galaviz-Ferman, M., Lopez, G., Lopez-Morteo, G., \& AndradeArechiga, M. (2006). Uso de objetos de aprendizaje interactivos para las matemáticas por maestros de secundaria. Paper presented at the Avances en las Ciencias de la Computación, VII Encuentro Internacional de Ciencias de la Computación ENC’06.

Garrison, R., Cleveland-Innes, M., \& Fung, T. (2004). Student role adjustment in online communities of inquiry: Model and instrument validation. Journal of Asynchronous Learning Networks, 8, 61-74.

IESALC (2006-2009). IESALC reports, special edition. From Cartagena to Paris. CRES 2008, WCHE 2009. Collection higher education in the Caribbean. Series: National reports (p. 351). International Institute of UNESCO for Higher Education in the Latin America and the Caribbean.

INEGI (2005). Anuario de Estadísticas por Entidad Federativa. Edición 2005. Aguascalientes, Ags: Instituto Nacional de Estadística, Geografía e Informática.

King, J. (2007). Educating engineers for the 21st century. Report Published by The Royal Academy of Engineering (pp. 1-37).

King, R. (2008). Addressing the supply and quality of engineering graduates for the new century (pp. 1-150).

Kuenzi, J. (2008). Science, technology, engineering, and mathematics (STEM) education: Background, federal policy, and legislative action. CRS Report for Congress. 
Lazakidou, G., \& Retalis, S. (2010). Using computer supported collaborative learning strategies for helping students acquire self-regulated problem-solving skills in mathematics. Computers \& Education, 54, 3-13. http://dx.doi.org/10.1016/j.compedu.2009.02.020

Lopez-Morteo, G., \& Lopez, G. (2007). Computer support for learning mathematics: A learning environment based on recreational learning objects. Computers \& Education, 48, 618-641. http://dx.doi.org/10.1016/j.compedu.2005.04.014

Lopez-Morteo, G., Galaviz-Ferman, M., Lopez, G., \& Andrade-Arechiga, M. (2007). The use of interactive instructors of recreational mathematics in secondary schools. 3rd International Conference on Web Information Systems and Technologies (WEBIST 2007), Barcelona, 554-558.

Madrigal, J., \& Gozalo, L. (2007). Descartes project and Mathema TICs: A sample of the Spanish Experience (pp. 1-11).

Mason, J. (2001). Mathematical teaching practices at tertiary level: Working group report. In D. Holton (Ed.), Teaching and learning of mathematics at university level: An ICMI study (pp. 71-86). Netherlands: Kluwer Academic Publishers.

Montaser, L., Mortada, M., \& Fawzy, S. (2012). Impact of technology on the future of education. EDULEARN12 Proceedings, 3881-3887.

Mustoe, L. (2002). Mathematics in engineering education. European Journal of Engineering Education, 27, 237-240.

http://dx.doi.org/10.1080/0304790210141546

Neto, M., Do Carmo, M., Silva, N., \& Macedo, F. (2003). Teaching and learning conceptions in Engineering Education: An innovative approach on Mathematics. European Journal of Engineering Education, 28, 523-534. http://dx.doi.org/10.1080/0304379032000101791

Nguyen, D., Hsieh, Y., \& Allen, D. (2006). The impact of web-based assessment and practice on students' mathematics learning attitudes. Journal of Computers in Mathematics and Science Teaching, 25, 251-279.

NSF (2006-2010). Science and engineering indicators-2006, 2008 \&
2010. Reports 2006, 2008 \& 2010 (Vol. 2, p. 576), National Science Foundation.

OECD (2003). Education at a glance 2003. Report (p. 454). Organisation for Economic Co-operation and Development.

OECD (2006). Education at a glance 2006. Report (p. 449). Organisation for Economic Co-operation and Development.

OECD (2007). OECD. Stat web browser. http://stats.oecd.org/wbos/Default.aspx

Oncu, S., Delialioglu, O., \& Brown, C. (2008). Critical components for technology integration: How do instructors make decisions? Journal of Computers in Mathematics and Science Teaching, 27, 19-46.

Popovic, C. (2010). Myth busting: An examination of teachers' beliefs about first-year medical students. How well do teachers know their students? Innovations in Education and Teaching International, 47, 141-154. http://dx.doi.org/10.1080/14703291003718885

Puryear, J., \& Ortega Goodspeed, T. (2011). How can education help latin america develop? Global Journal of Emerging Market Economies, 3, 111-134. http://dx.doi.org/10.1177/097491011000300104

Schwab, K. (2008-2010). The Global Competitiveness Reports 20082009, 2009-2010 \& 2010-2011. Published by the World Economic Forum within the framework of the Global Competitiveness Network (p. 513). World Economic Forum. Committed to improving the state of the world.

SEP (2004). Programa enciclomedia documento base (p. 14). Subsecretaría de Educación Básica y Normal.

SEP (2006). Programa enciclomedia. Libro Blanco: Secretaría de Educación Pública. Report, 57.

UNESCO (2009). GLOBAL EDUCATION DIGEST 2009 Comparing Education Statistics across the World. Report Published by UNESCO Institute for Statistics (p. 264).

UNESCO (2011). Regional report on education for all in Latin America and the Caribbean. Report by Regional Bureau for Education in Latin America and the Caribbean OREALC/UNESCO. 